\title{
PROTECTIVE EFFECT OF DIVALENT CATIONS AGAINST ALUMINUM TOXICITY IN SOYBEAN ${ }^{(1)}$
}

\author{
Ivo Ribeiro da Silva ${ }^{(2)}$, Tarcísio Fernando Côrtes Corrêa ${ }^{(3)}$, Roberto \\ Ferreira Novais ${ }^{(2)}$, Fabrício de Oliveira Gebrim ${ }^{(4)}$, Flancer Novais \\ Nunes $^{(4)}$, Eulene Francisco da Silva ${ }^{(4)} \&$ Thomas Jot Smyth ${ }^{(5)}$
}

\begin{abstract}
SUMMARY
A large proportion of soybean fields in Brazil are currently cultivated in the Cerrado region, where the area planted with this crop is growing considerably every year. Soybean cultivation in acid soils is also increasing worldwide. Since the levels of toxic aluminum ( $\mathrm{Al}$ ) in these acid soils is usually high it is important to understand how cations can reduce $\mathrm{Al}$ rhizotoxicity in soybean. In the present study we evaluated the ameliorative effect of nine divalent cations ( $\mathrm{Ca}, \mathrm{Mg}, \mathrm{Mn}, \mathrm{Sr}$, $\mathrm{Sn}, \mathrm{Cu}, \mathrm{Zn}, \mathrm{Co}$ and $\mathrm{Ba}$ ) in solution culture on $\mathrm{Al}$ rhizotoxicity in soybean. The growth benefit of $\mathrm{Ca}$ and $\mathrm{Mg}$ to plants in an acid Inceptisol was also evaluated. In this experiment soil exchangeable $\mathrm{Ca}: \mathrm{Mg}$ ratios were adjusted to reach 10 and $60 \%$ base saturation, controlled by different amounts of $\mathrm{CaCl}_{2}$ or $\mathrm{MgCl}_{2}$ (at proportions from 100:0 up to 0:100), without altering the soil pH level. The low (10\%) and adequate (60\%) base saturation were used to examine how plant roots respond to $\mathrm{Al}$ at distinct $(\mathrm{Ca}+\mathrm{Mg}) / \mathrm{Al}$ ratios, as if they were growing in soils with distinct acidity levels. Negative and positive control treatments consisted of absence (under native soil or undisturbed conditions) or presence of lime $\left(\mathrm{CaCO}_{3}\right)$ to reach 10 and $60 \%$ base saturation, respectively. It was observed that in the absence of Aluminum, $\mathrm{Cu}, \mathrm{Zn}$, Co and $\mathrm{Sn}$ were toxic even at a low concentration $\left(25 \mu \mathrm{mol} \mathrm{L} \mathrm{L}^{-1}\right)$, while the effect of $\mathrm{Mn}, \mathrm{Ba}, \mathrm{Sr}$ and $\mathrm{Mg}$ was positive or absent on soybean root elongation when used in concentrations up to $100 \mu \mathrm{mol} \mathrm{L} \mathrm{L}^{-1}$. At a level of $10 \mu \mathrm{mol} \mathrm{L} \mathrm{L}^{-1} \mathrm{Al}$, root growth was only reverted to the level of control plants by the Mg treatment. Higher Tin doses led to a small alleviation of $\mathrm{Al}$ rhizotoxicity, while the other cations reduced root growth or had no effect. This is an indication that the Mg effect is ion-specific and not associated to an electrostatic protection mechanism only, since all ions were divalent and used at low concentrations. An increased exchangeable Ca:Mg
\end{abstract}

\footnotetext{
(1) Recebido para publicação em outubro de 2006 e aprovado em outubro de 2008.

(2) Professor do Departamento de Solos, Universidade Federal de Viçosa - UFV. Av. PH Rolfs s/n, CEP 36570-000 Viçosa (MG). E-mails: ivosilva@ufv.br

(3) Graduando em Agronomia, Departamento de Solos, UFV. Bolsista do CNPq.

(4) Doutorando em Solos e Nutrição de Plantas, Departamento de Solos, UFV.

${ }^{(5)}$ Soil Science Department, North Carolina State University. Raleigh, NC, USA.
} 
ratio (at constant soil $\mathrm{pH}$ ) in the acid soil almost doubled the soybean shoot and root dry matter even though treatments did not modify soil $\mathrm{pH}$ and exchangeable $\mathrm{Al}^{3+}$. This indicates a more efficient alleviation of $\mathrm{Al}$ toxicity by $\mathrm{Mg}^{2+}$ than by $\mathrm{Ca}^{2+}$. The reason for the positive response to $\mathrm{Mg}^{2+}$ was not the supply of a deficient nutrient because $\mathrm{CaCO}_{3}$ increased soybean growth by increasing soil $\mathrm{pH}$ without inducing $\mathrm{Mg}^{2+}$ deficiency. Both in hydroponics and acid soil, the reduction in $\mathrm{Al}$ toxicity was accompanied by a lower $\mathrm{Al}$ accumulation in plant tissue, suggesting a competitive cation absorption and/or exclusion of Al from plant tissue stimulated by an Mg-induced physiological mechanism.

Index terms: heavy metals, cation amelioration, soil acidity, Ca:Mg ratio

\title{
RESUMO: EFEITO PROTETOR DE CÁTIONS DIVALENTES CONTRA A TOXIDEZ DE ALUMÍNIO EM SOJA
}

\begin{abstract}
Uma grande parte da soja no Brazil é cultivada atualmente na região do Cerrado, e é nessa região que ocorre a maior expansão da cultura. Nessa região, a maioria dos solos é ácida e, geralmente, apresenta níveis elevados de alumínio (Al) tóxico. Portanto, é importante compreender como determinados cátions reduzem a rizotoxidez de Al em plantas de soja. Neste estudo foram avaliados, em solução nutritiva, o efeito protetor de nove cátions divalentes ( $\mathrm{Ca}, \mathrm{Mg}, \mathrm{Mn}, \mathrm{Sr}, \mathrm{Sn}, \mathrm{Cu}, \mathrm{Zn}$, Co and $\mathrm{Ba}$ ) contra a rizotoxidez de $\mathrm{Al}$ e o efeito positivo do Ca e Mg no crescimento das plantas de soja num solo com elevada saturação por Al. A relação entre Ca e $\mathrm{Mg}$ trocáveis foi variada por meio de adição de diferentes quantidades de $\mathrm{CaCl}_{2}$ ou $\mathrm{MgCl}_{2}$ (com as proporções variando entre 100:0 até 0:100), sem que ocorresse alteração no $\mathrm{pH}$ do solo. Tratamentos testemunhas consistiram de solo sem aplicação ou com aplicação de calcário $\left(\mathrm{CaCO}_{3}\right)$. Foi observado que, na ausência do Al, os cátions $\mathrm{Cu}, \mathrm{Zn}$, Co e Sn foram tóxicos mesmo em baixas concentrações (25 $\left.\mu \mathrm{mol} \mathrm{L} \mathrm{L}^{-1}\right)$, enquanto $\mathrm{Mn}, \mathrm{Ba}, \mathrm{Sr}$ e $\mathrm{Mg}$ em concentrações até $100 \mu \mathrm{mol} \mathrm{L} \mathrm{L}^{-1}$ apresentaram nenhum efeito ou efeito positivo no elongamento radicular da soja. Com $10 \mu \mathrm{mol} \mathrm{L^{-1 }}$ de Al, apenas no tratamento com $M g$ as raízes apresentaram recuperação no elongamento para o mesmo patamar que o tratamento controle sem Al. O Sn em doses elevadas proporcionou uma pequena melhora na rizotoxidez de Al, enquanto outros cátions divalentes tiveram nenhum efeito ou reduziram o crescimento radicular. Isso é uma indicação de que o efeito do $\mathrm{Mg}$ é específico e não está apenas associado a uma proteção por meio de efeito eletrostático, porque todos os outros cátions usados eram divalentes e foram fornecidos em baixas concentrações. No experimento com solo ácido, observou-se que a redução da relação Ca: $\mathrm{Mg}$ trocáveis praticamente dobrou o acúmulo de matéria seca da parte aérea e das raízes, embora os tratamentos não tenham modificados o $\mathrm{pH}$ do solo e o $\mathrm{Al}^{3+}$ trocável, suportando o maior efeito protetor do Mg contra o $\mathrm{Al}^{3+}$ em relação ao Ca. A resposta positiva ao Mg não foi devida ao suprimento do nutriente que se encontrava deficiente, pois a aplicação de $\mathrm{CaCO}_{3}$ melhorou o crescimento radicular por meio do incremento do $\mathrm{pH}$ (e precipitação do $\mathrm{Al}^{3+}$ ) sem induzir deficiência de $\mathrm{Mg}$. Tanto em condições hidropônicas quanto no solo ácido, a redução na toxidez do $\mathrm{Al}^{3+}$ foi acompanhada por menor acúmulo de $\mathrm{Al}$ no tecido vegetal, sugerindo a ocorrência de inibição competitiva na absorção, e, ou , exclusão do Al na rizosfera em resposta a um mecanismo fisiológico promovido pelo $\mathrm{Mg}$.
\end{abstract}

Termos de indexação: metais pesados, efeito protetor de cátions, acidez do solo, relação $\mathrm{Ca}: \mathrm{Mg}$.

\section{INTRODUCTION}

Soybean is one of the most important export crops grown in Brazil. A vast area of soybean fields is currently cultivated in the Cerrado region, and increases considerably every year. Acid soils with variable charge minerals (kaolinite and oxides) have low bases saturation (Silva et al., 2008). In this region, acidity levels of more than $50 \%$ of the soils are high and aluminum (Al) levels in the surface and subsurface layers are toxic (Eswaran, 1997; Lopes, 1983). Grain yield of several crops was shown to be reduced by base saturation lower than $60 \%$ and enchageable $\mathrm{Al}^{3+}$ greater than $0,3 \mathrm{cmol}_{\mathrm{c}} \mathrm{dm}^{-3}$ (Nicolodi et al., 2008). This makes liming a key practice of soil fertility management (Lopes, 1996). A better understanding 
of related issues and enhanced management will benefit this as well as other regions, since soybean cultivation in acid soils is quickly expanding worldwide.

Although there is significant variation for $\mathrm{Al}$ tolerance among soybean genotypes (Sartain \& Kamprath, 1978; Spehar, 1994; Menosso et al., 2000; Silva et al., 2000), the species is relatively sensitive to soil acidity in comparison with other crop and tree species (Moyer-Henry et al., 2003). Several studies have reported substantial gains in growth and yield in acid soils treated with lime (Oliveira \& Pavan, 1996; Martins et al., 1998; Fageria, 2001). The positive effects of liming on acid soils are numerous, and the reduction of $\mathrm{Al}$ toxicity is certainly one of the most beneficial. Knowledge on the amelioration of $\mathrm{Al}$ toxicity due to its precipitation as low solubility Alhydroxides under higher soil $\mathrm{pH}$ is not new, but the effects of basic cations (mainly $\mathrm{Ca}$ and $\mathrm{Mg}$ ) on the reduction of the deleterious effect of $\mathrm{Al}$ have almost always been overlooked. Experiments in hydroponics have clearly shown that basic cations are able to alleviate Al toxicity in soybean (Alva et al., 1986; Ferrufino et al., 2000; Silva et al., 2001a). In fact, soybean responses to liming in high $\mathrm{Al}$ soils with sufficient $\mathrm{Ca}$ and $\mathrm{Mg}$ availability are usually low or insignificant (Caires et al., 1998, 2003). Conversely, substantial responses to liming have been observed in soils with high $\mathrm{Al}$ and lower cation availability (Martins et al., 1998; Fageria, 2001).

Previous research has shown that the ability of cations to reduce $\mathrm{Al}^{3+}$ toxicity, except for the small cation $\mathrm{H}^{+}$, is directly related to their valences in the order: $\mathrm{H}^{+}>\mathrm{C}^{3+}>\mathrm{C}^{2+}>\mathrm{C}^{1+}$ (Kinraide \& Parker, 1987; Grauer \& Horst, 1992; Kinraide et al., 1992, 1994a; Kinraide, 1998). However, it seems that the amelioration of $\mathrm{Al}$ toxicity by cations is not only a matter of a competitive effect with $\mathrm{Al}$ by absorption sites at the root surface because cations of a same valence may have a distinct, species-dependent ameliorative effect. For example, it was observed that $\mathrm{Ca}$ and $\mathrm{Mg}$ confer a similar protection against $\mathrm{Al}$ toxicity in wheat (Kinraide, 1998), but there are results in hydroponics indicating that $\mathrm{Mg}$ is more efficient than $\mathrm{Ca}$ in soybean (Silva et al., 2001a,b). Under field conditions it was found that $\mathrm{Mg}$ has a fundamental function against $\mathrm{Al}$ toxicity because the response of soybean yield to liming increases as a consequence of greater availability and $\mathrm{Mg}$ uptake (Caires et al., 2001). It is currently not known whether other divalent cations have a similar ameliorative effect as $\mathrm{Mg}^{2+}$ and whether $\mathrm{Mg}^{2+}$ is equally protective in soil as in hydroponic conditions. This study investigates the protective role of physiologically relevant concentrations of several divalent cations against $\mathrm{Al}^{3+}$ rhizotoxicity in soybean and evaluates whether the beneficial effects of $\mathrm{Mg}^{2+}$ can be extended from hydroponics to soil conditions.

\section{MATERIAL AND METHODS}

Experiment 1: Protective effect of divalent cations against Al rhizotoxicity in solution culture

Soybean seeds of the cultivars UFV-16 (Al-tolerant) and Confiança (Al-sensitive) were germinated on $0.01 \mathrm{mmol} \mathrm{L}^{-1} \mathrm{CaSO}_{4}$ - soaked germination paper at $25^{\circ} \mathrm{C}$ for $72 \mathrm{~h}$. Six to eight uniform seedlings of each cultivar were transferred to plastic trays containing $10 \mathrm{~L}$ of aerated solution culture with $0.5 \mathrm{mmol} \mathrm{L}^{-1}$ $\mathrm{CaCl}_{2}$. The solution $\mathrm{pH}$ had previously been adjusted to 4.5 with $0.1 \mathrm{mmol} \mathrm{L}^{-1} \mathrm{H}_{2} \mathrm{SO}_{4}$, to avoid $\mathrm{Al}$ precipitation.

Treatments were analyzed in a $8 \times 2$ factorial design of eight divalent cations $\left(\mathrm{Mg}^{2+}, \mathrm{Zn}^{2+}, \mathrm{Cu}^{2+}\right.$, $\mathrm{Mn}^{2+}, \mathrm{Sr}^{2+}, \mathrm{Sn}^{2+}, \mathrm{Co}^{2+}$ and $\left.\mathrm{Ba}^{2+}\right)$, either in the absence or presence of $10 \mu \mathrm{mol} \mathrm{L}{ }^{-1} \mathrm{Al}$. Due to the large number of experimental units, the experiment was run independently for the two soybean cultivars. The divalent cations were applied at 0, 25, 50 and $100 \mu \mathrm{mol} \mathrm{L}^{-1}$. Background Ca levels were varied from 0.4 to $0.5 \mathrm{mmol} \mathrm{L}^{-1}$ depending on the concentration of other divalent cations added, in order to maintain a constant ionic strength. The solution $\mathrm{pH}$ was adjusted daily to 4.5 by slowly adding $0.1 \mathrm{~mol} \mathrm{~L}^{-1} \mathrm{KOH}$ or $\mathrm{HCl}$ as required, under continuous stirring. The plants were grown in a greenhouse at $27 \pm 5^{\circ} \mathrm{C}$. After $16-18 \mathrm{~h}$ acclimation to the basal $\mathrm{CaCl}_{2}$ solution, the primary root length was measured and treatments initiated. Root length was measured again $90 \mathrm{~h}$ after treatment initiation. The experiments were arranged in a randomized block design, with three replicates of six seedlings each.

At harvest, roots and shoots were separated, dried for $72 \mathrm{~h}\left(70^{\circ} \mathrm{C}\right)$ in a forced draft oven, weighed, ground in a Wiley mill with a $1 \mathrm{~mm}$ stainless steel sieve and wet-digested with a nitro-perchloric mixture (3:1) according to Sarruge \& Haag (1974). After appropriate dilutions the element concentration was determined by ICP-AES.

Parallel experiments were run in hydroponics to evaluate the effect of $\mathrm{Ca}$ and $\mathrm{Mg}$ on root growth in more detail, under similar conditions as described above. Additional information on treatments is presented in the section Results and Discussion.

\section{Experiment 2: Effect of varying $\mathrm{Ca}: \mathrm{Mg}$ ratio on soybean growth in an acid soil}

In order to test the effectiveness of $\mathrm{Ca}$ and $\mathrm{Mg}$ as Al toxicity barrier in soil, soybean growth was evaluated in soil samples of the $0-20 \mathrm{~cm}$ layer of an Al-toxic sandy-loam Inceptisol with varying $\mathrm{Ca}$ and $\mathrm{Mg}$ ratios. After air-drying, sub-samples were taken for chemical and physical soil analysis. The soil consists of $18 \%$ clay, $11 \%$ silt, $36 \%$ fine sand and $35 \%$ coarse sand. Under native conditions the soil presented $\left(\mathrm{cmol}_{\mathrm{c}} \mathrm{kg}^{-1}\right): 0.10 \mathrm{Ca}, 0.04 \mathrm{Mg}$, and $1.00 \mathrm{Al}$. Except for the nutrients involved in the treatments, all macro and micronutrients were supplied in 
amounts to ensure optimal growth. Fourteen treatments were arranged in a $7 \times 2$ factorial design of seven $\mathrm{Ca}$ and, or $\mathrm{Mg}$ amendments, at two soil base saturations (10 and $60 \%$ ). The seven $\mathrm{Ca}$ and $\mathrm{Mg}$ treatments consisted of: (1) control with all nutrients (without $\mathrm{Ca}$ and $\mathrm{Mg}$ ). All nutrients except $\mathrm{Ca}$ and Mg were supplied in doses and sources according to Novais et al. (1991); (2) soil limed with $\mathrm{CaCO}_{3}$ to reach $60 \%$ base saturation (3.8 $\left.\mathrm{t} \mathrm{ha}^{-1}\right) ;$ (3) $\mathrm{Ca}+\mathrm{Mg}$ equivalent to $\mathrm{Ca}$ present in the $\mathrm{CaCO}_{3}$ applied in treatment 1, at 100:0 Ca:Mg; (4) $\mathrm{Ca}+\mathrm{Mg}$ equivalent to Ca present in the $\mathrm{CaCO}_{3}$ applied in treatment 1, at 75:25 Ca:Mg; (5) $\mathrm{Ca}+\mathrm{Mg}$ equivalent to Ca present in the $\mathrm{CaCO}_{3}$ applied in treatment 1, at 50:50 Ca:Mg; (6) $\mathrm{Ca}+\mathrm{Mg}$ equivalent to $\mathrm{Ca}$ present in the $\mathrm{CaCO}_{3}$ applied in treatment 1 , at 25:75 $\mathrm{Ca}: \mathrm{Mg}$, and (7) $\mathrm{Ca}+\mathrm{Mg}$ equivalent to Ca present in the $\mathrm{CaCO}_{3}$ applied in treatment 1, at 00:100 Ca:Mg. In treatments 3 to 7 and 8 to $14 \mathrm{Ca}$ and $\mathrm{Mg}$ were supplied as chloride salts to avoid changes in soil $\mathrm{pH}, \mathrm{Al}$ precipitation and Al complexation, thus minimizing the chance for confounding effects. Treatments 8 to 14 were the same as described above, except that a lower lime dose (10\% base saturation) was used. The low (10\%) and adequate $(60 \%)$ base saturation were created to examine how plant roots would respond to $\mathrm{Al}$ at distinct $(\mathrm{Ca}+\mathrm{Mg}) / \mathrm{Al}$ ratios, as if they were growing in soils with distinct acidity limitations. After treatment application, the soil moisture was adjusted

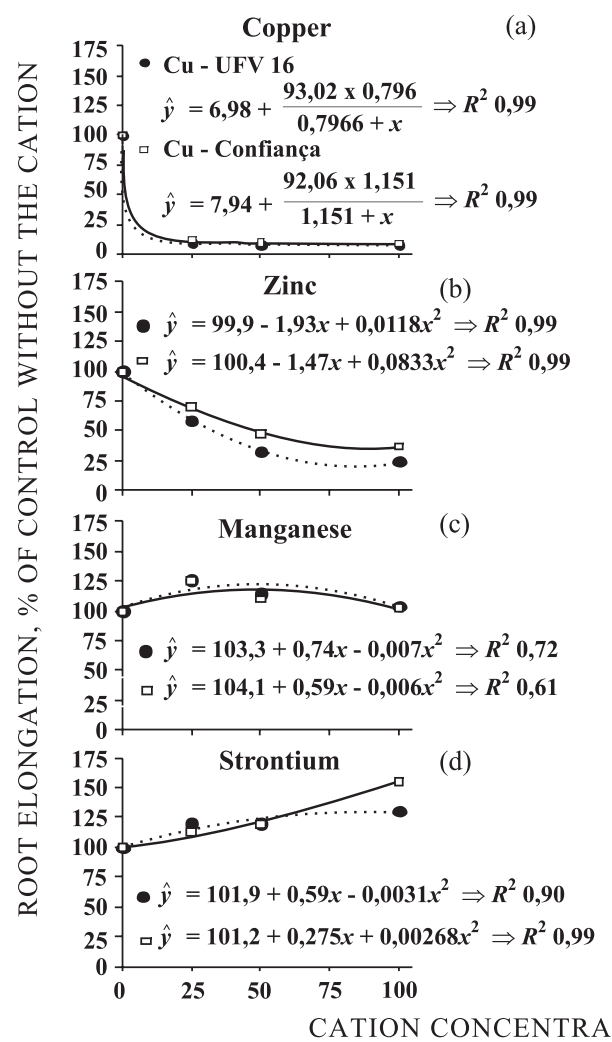

to field capacity and incubated for two weeks in a greenhouse. Thereafter, it was air-dried, weighed $(0.8 \mathrm{~kg})$ and transferred to $1 \mathrm{~L}$ plastic pots. Six seeds of soybean cv. UFVS-2001 were sown in each pot and three days after germination, seedlings were thinned to the three most regular in size. Pots were watered twice a day with deionized water in order to maintain moisture at around $80 \%$ of field capacity. Two weeks days after germination the plants (vegetative stage between $V_{2}$ and $V_{3}$ ) were removed from pots, separated in shoot and roots, dried at $70^{\circ} \mathrm{C}$ and then weighed to the fourth decimal place. The material was wetdigested in a nitro-perchloric acid mixture and the $\mathrm{Ca}, \mathrm{Mg}$ and $\mathrm{Al}$ concentrations were measured in the extracts as described above.

\section{RESULTS AND DISCUSSION}

\section{Protective effect of $\mathrm{Mg}$ and other divalent cations against Al rhizotoxicity}

In the first part of this study the effect of several divalent cations on the elongation of soybean roots was evaluated in the absence and presence of $\mathrm{Al}^{3+}$ in solution. The differences among divalent cations regarding their effects on root elongation were marked, statistically significant $(\mathrm{p}<0.05)$ (Figures 1 and 2 ). In control solutions without $\mathrm{Al}^{3+}$, cations such as $\mathrm{Cu}^{2+}$,

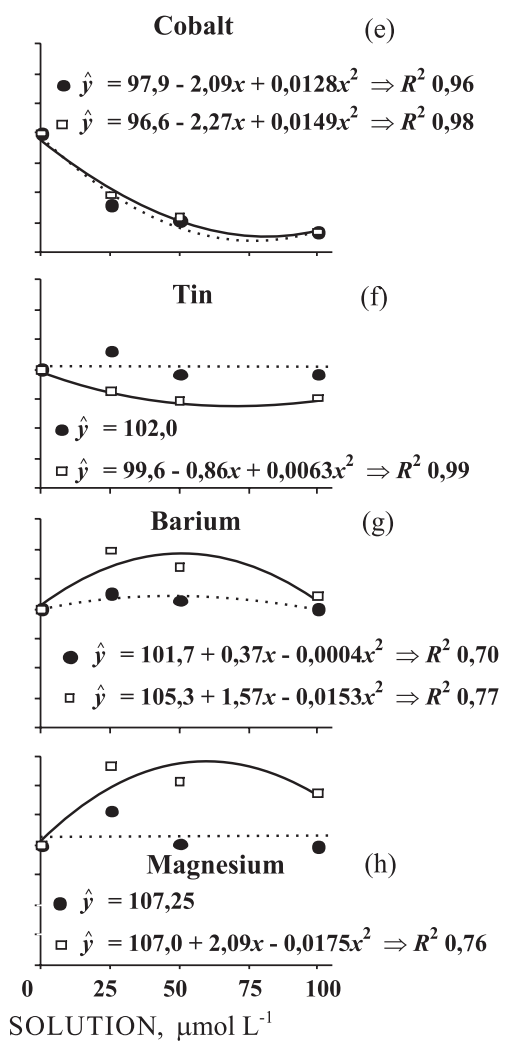

Figure 1. Relative root elongation of soybean cultivars UFV-16 and Confiança as a function of increasing doses of divalent cations in $\mathrm{CaCl}_{2} 500 \mathrm{mmol} \mathrm{L}^{-1}(\mathrm{pH} 4.5)$ basal solution, in the absence of Al. Error bars represent standard error $(n=3)$. 


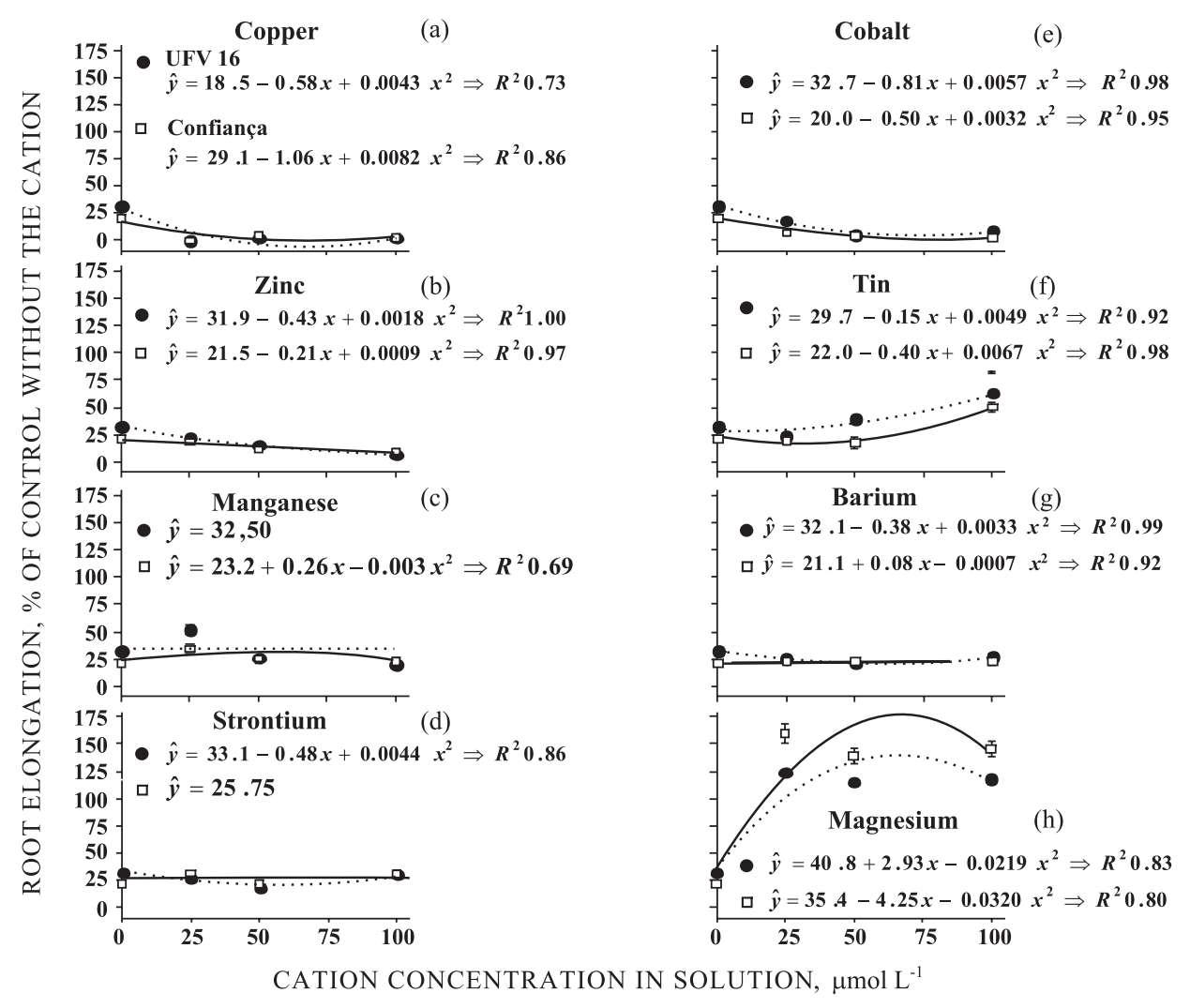

Figure 2. Relative root elongation of soybean cultivars UFV-16 and Confiança as a function of increasing doses of divalent cations in a $\mathrm{CaCl}_{2} 500 \mathrm{mmol} \mathrm{L}^{-1}(\mathrm{pH} 4.5)$ basal solution, in the presence of $10 \mu \mathrm{mol} \mathrm{L}^{-1}$ Al. Error bars represent standard error $(n=3)$.

$\mathrm{Zn}^{2+}$ and $\mathrm{Co}^{2+}$ were highly toxic to both soybean cultivars, drastically reducing root elongation even at the lowest concentration (Figure 1). Previous studies have also shown that $\mathrm{Cu}^{2+}$ and $\mathrm{Zn}^{2+}$ at low doses were highly toxic to plant roots (Kinraide et al., 2004; Pedler et al., 2004). Tin was slightly toxic to cv. Confiança only. Although $\mathrm{Cu}^{2+}$ and $\mathrm{Zn}^{2+}$ are essential elements for plant growth, they are required at low concentrations (less than $10 \mu \mathrm{mol} \mathrm{L}{ }^{-1}$ ) in solution, while excess supply leads to toxicity, with a consequent reduction of plant growth. Cobalt is only considered a beneficial (non-essential) element for plants, but is essential for $\mathrm{N}_{2}$-fixing bacteria (Marschner, 1995). The effect on root elongation of the other cations $\left(\mathrm{Mn}^{2+}, \mathrm{Ba}^{2+}, \mathrm{Sr}^{2+}\right.$ and $\left.\mathrm{Mg}^{2+}\right)$, mainly the last three, was positive $(\mathrm{p}<0.05)$. The positive effect of these cations is possibly related to alleviation of $\mathrm{H}^{+}$toxicity (Kinraide, 1991) at low $\mathrm{pH}$ levels, as used here, rather than a response to nutrient deficiency in the growth medium. The beneficial effects of $\mathrm{Ba}^{2+}$ and $\mathrm{Sr}^{2+}$, which are non-essential elements for plants, seem to support this hypothesis.

The two genotypes differed $(p<0.05)$ in response to solution Al. In solutions containing $10 \mu \mathrm{mol} \mathrm{L}-1 \mathrm{Al}$ (in $500 \mu \mathrm{mol} \mathrm{L}^{-1} \mathrm{CaCl}_{2}$ background) and with addition of no other divalent cation, root growth of cv. Confiança was reduced by approximately $75 \%$, and around $55 \%$ in cv. UFV-16. This differential Al tolerance of soybean genotypes has been reported previously (Sartain \& Kamprath, 1978; Spehar, 1994; Menosso et al., 2000; Silva et al., 2000) and is related to the ability of Al-tolerant plants to produce and secrete organic acids, particularly citrate, in the presence of Al (Yang et al., 2000; Menosso et al., 2001; Silva et al., 2001a).

The addition of increasing amounts of $\mathrm{Mn}^{2+}, \mathrm{Sr}^{2+}$ and $\mathrm{Ba}^{2+}$ led to no substantial improvement in root elongation of both soybean cultivars. Cobalt, $\mathrm{Zn}^{2+}$, $\mathrm{Cu}^{2+}$ and $\mathrm{Sn}^{2+}$ even aggravated the $\mathrm{Al}$ rhizotoxicity (Figure 2), probably as a result of their intrinsic toxicity in the absence of $\mathrm{Al}^{3+}$ (Figure 1). In contrast, the toxic effect of $\mathrm{Al}$ on root growth of both soybean cvs. was eliminated with the addition of as little as $25 \mu \mathrm{mol} \mathrm{L}{ }^{-1} \mathrm{Mg}^{2+}$ (Figure 2). The improvement in root elongation by $\mathrm{Mg}$ was paralleled by a reduced $\mathrm{Al}$ concentration in root tissue (Figure $3 \mathrm{~h}$ ). This was not restricted to $\mathrm{Mg}$ since increasing doses of all cations led to a reduced $\mathrm{Al}$ concentration in roots, with exception of $\mathrm{Sr}^{2+}$ and $\mathrm{Ca}^{2+}$. The former reduced $\mathrm{Al}$ accumulation up to a dose of $50 \mu \mathrm{mol} \mathrm{L}^{-1}$ and the latter was not very effective in reducing $\mathrm{Al}$ accumulation in the root (Figure 3).

The high $\mathrm{Ca}^{2+}$ demand in the growth medium to maintain normal root elongation (Kinraide, 1998; 


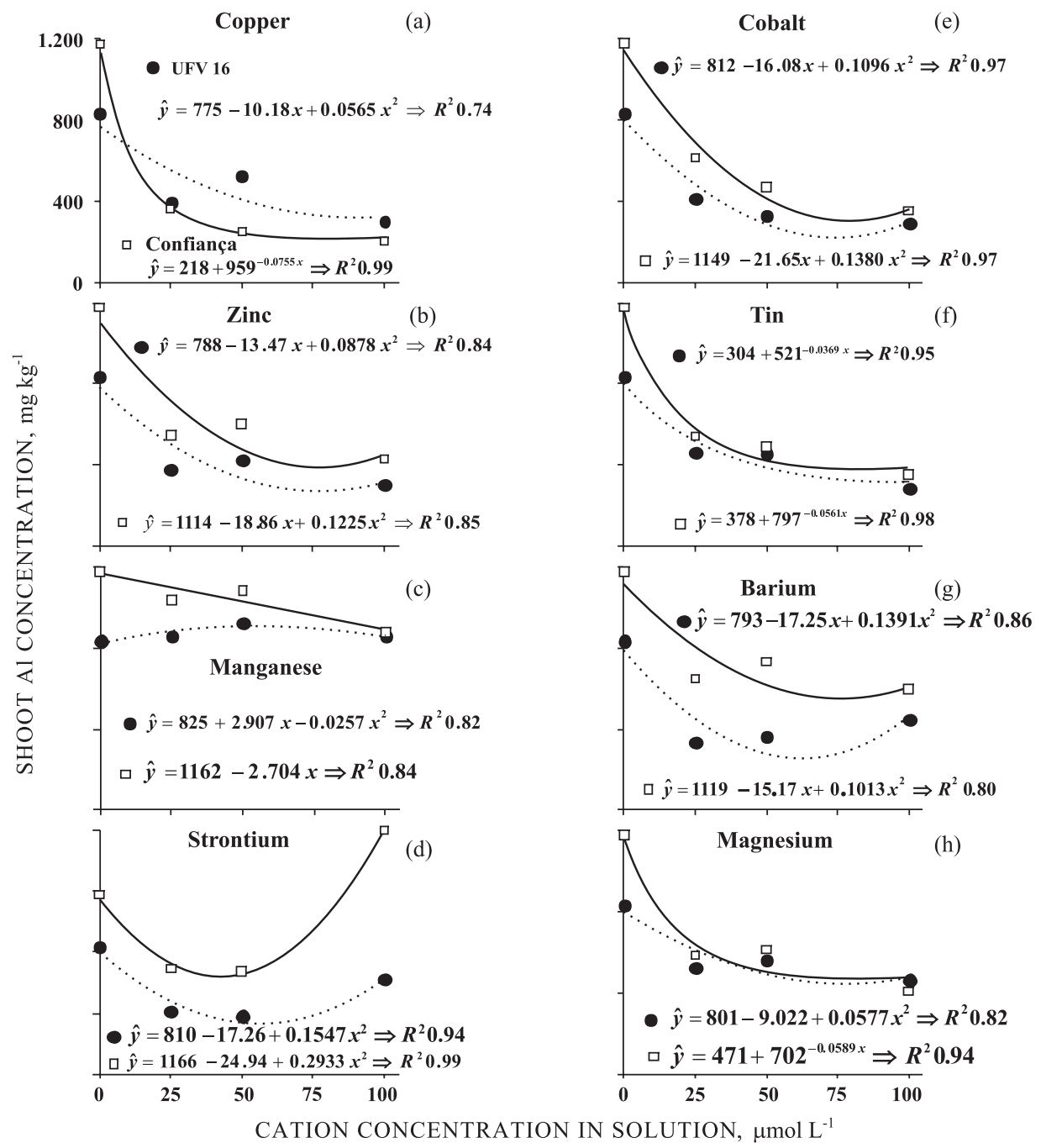

Figure 3. Aluminum concentration in roots of soybean cvs. UFV-16 and Confiança as a function of increasing doses of divalent cations in a $\mathrm{CaCl}_{2} 500 \mathrm{mmol} \mathrm{L}^{-1}(\mathrm{pH} 4.5)$ basal solution, in the presence of $10 \mu \mathrm{mol} \mathrm{L}^{-1}$ Al. Error bars represent standard error $(n=3)$.

Sanzonowicz et al., 1998; Silva et al., 2001b) negates a separate analysis of the beneficial effects of supplying a deficient nutrient from others related to the alleviation of $\mathrm{Al}$ damage. In the solution without $\mathrm{Al}$, the absence of $\mathrm{Ca}^{2+}$ (deionized water, $\mathrm{pH} 4.5$ ) completely inhibited root elongation, which reached normal growth only when at least $250 \mu \mathrm{mol} \mathrm{L}-1 \mathrm{Ca}^{2+}$ was present in the solution (Figure 4a). When $\mathrm{Ca}^{2+}$ was supplied at a non-limiting concentration (> $250 \mu \mathrm{mol} \mathrm{L}{ }^{-1} ; \mathrm{pH} 4.5$ ), the presence of $10 \mu \mathrm{mol} \mathrm{L}{ }^{-1}$ Al limited root elongation by more than $50 \%$ (Figure 4a), which confirms the lower protective effect of $\mathrm{Ca}^{2+}$ (Figure 4a) in comparison to $\mathrm{Mg}^{2+}$ (Figure 5). In fact, only $500 \mu \mathrm{mol} \mathrm{L}-1 \mathrm{Ca}^{2+}$ was sufficient to completely alleviate the deleterious effect of $10 \mu \mathrm{mol} \mathrm{L}^{-1}$ $\mathrm{Al}$ on soybean root growth with $25 \mu \mathrm{mol} \mathrm{L}{ }^{-1} \mathrm{Mg}^{2+}$ in the solution.

It has been shown that strontium is able to substitute for $\mathrm{Ca}$ in the dimerization of pectic compounds of the cell wall in vitro $\left(\mathrm{O}^{\prime}\right.$ Neill et al., 1996). The possibility of using $\mathrm{Sr}^{2+}$ in substitution of $\mathrm{Ca}^{2+}$ in solution would allow a more accurate quantification of the ameliorative effect of $\mathrm{Ca}$ on $\mathrm{Al}$ rhizotoxicity. However, $\mathrm{Sr}^{2+}$ alone was unable to substitute $\mathrm{Ca}^{2+}$, leading to restricted root elongation even in Al-free solution (Figure 4b). The protective effect of cations at low concentrations (micromolar range) against $\mathrm{Al}$ rhizotoxicity in soybean therefore seems to be somewhat ion-specific. The mitigating effect of $\mathrm{Mg}^{2+}$ is not due do an increase in the ionic strength, which was maintained constant in all treatments. Moreover, since all cations evaluated were divalent, it is unlikely that the ameliorative effect of $\mathrm{Mg}^{2+}$ was associated to $\mathrm{Al}$ displacement from the root cell surface. The low cation concentrations employed do not support the explanation of a protective action based on the increase of the electrical potential of root cell plasma membrane either (Kinraide et al., 


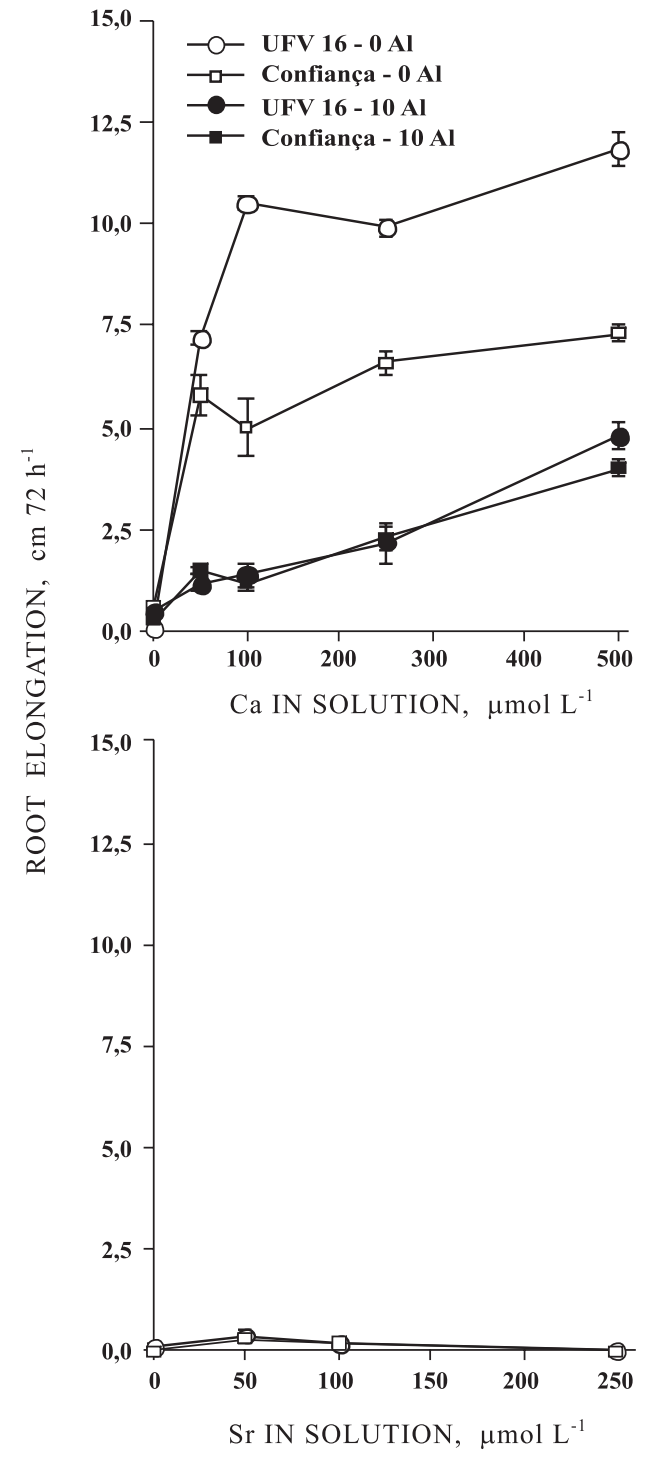

Figure 4. Root elongation of soybean cultivars UFV16 and Confiança as a function of increasing $\mathrm{Ca}$ (a) or $\mathrm{Sr}$ (b) in solution (pH 4.5), in the absence or presence of $10 \mu \mathrm{mol} \mathrm{L}{ }^{-1}$ Al. Error bars represent standard error $(n=3)$.

1992; Kinraide, 1994b, 1998). In wheat, Pedler et al. (2004) found that low $\mathrm{Mg}^{2+}$ doses were able to completely alleviate $\mathrm{Zn}^{2+}$ rhizotoxicity, while $\mathrm{Ca}$ amelioration, even at much higher doses, was much weaker. The nature of this protective role of $\mathrm{Mg}^{2+}$ is not quite clear at the moment, but the high effectiveness of low $\mathrm{Mg}^{2+}$ concentrations indicates the involvement of a biochemical/physiological mechanism. One possibility could be the stimulatory function by $\mathrm{Mg}^{2+}$ on the biosynthesis and citric acid secretion by soybean root tips in the presence of $\mathrm{Al}$ (Silva et al., 2001c). Since citric acid is a potent Al chelator, it could well be involved in $\mathrm{Al}$ detoxification in the rizosphere or within root tip cells (Ma et al., 2001; Ryan et al., 2001). Due to the ionic radii similarity, an Al uptake blockage due to competitive transport (Macdiarmid \& Gardner, 1996) can not be completely ruled out.

\section{Calcium and magnesium effects on soybean growth in acid soil}

We further tested the protective effect of $\mathrm{Ca}$ and $\mathrm{Mg}$ by growing soybean on an acid, Al-toxic soil under variable $\mathrm{Ca}^{2+}$ and $\mathrm{Mg}^{2+}$ availability. For the purpose of comparison, the treatments liming (plus all nutrients but $\mathrm{Ca}^{2+}$ and $\mathrm{Mg}^{2+}$ ) and control (no liming plus all nutrients, except $\mathrm{Ca}^{2+}$ and $\mathrm{Mg}^{2+}$ ) were established (Table 1). A decreasing exchangeable $\mathrm{Ca}: \mathrm{Mg}$ ratio in the soil from 26 to 0.17 (Table 1) almost doubled soybean shoot and root dry matter $\mathrm{f}$ (Figure 6). A similar trend was observed for the treatment with smaller amounts of $\mathrm{Ca}$ and $\mathrm{Mg}$ application (10\% base saturation). Interestingly, these treatments did not substantially modify the soil $\mathrm{pH}$ and exchangeable $\mathrm{Al}^{3+}$, thus indicating a more efficient alleviation of $\mathrm{Al}$ toxicity by $\mathrm{Mg}^{2+}$ than by $\mathrm{Ca}^{2+}$. These results also show that the existing exchangeable $\mathrm{Ca}^{2+}$ in the soil was not limiting, otherwise no response to $\mathrm{Mg}^{2+}$ would have been observed. The positive response to $\mathrm{Mg}^{2+}$ was not due to a supply of a deficient nutrient because $\mathrm{CaCO}_{3}$ increased soybean growth by increasing soil $\mathrm{pH}$ and precipitating toxic $\mathrm{Al}$ without inducing $\mathrm{Mg}^{2+}$ deficiency, as observed for other acid, Mg-deficient soils (Tan et al., 1992).

A low lime dose (10\% saturation) was sufficient to raise soil $\mathrm{pH}$ from 4.4 to 5.1 and improved shoot growth. Nevertheless, root growth was still limited under such conditions (Figure 6a). It appears that the remaining $0.6 \mathrm{cmol}_{\mathrm{c}} \mathrm{dm}^{-3} \mathrm{Al}^{3+}$ in the soil was

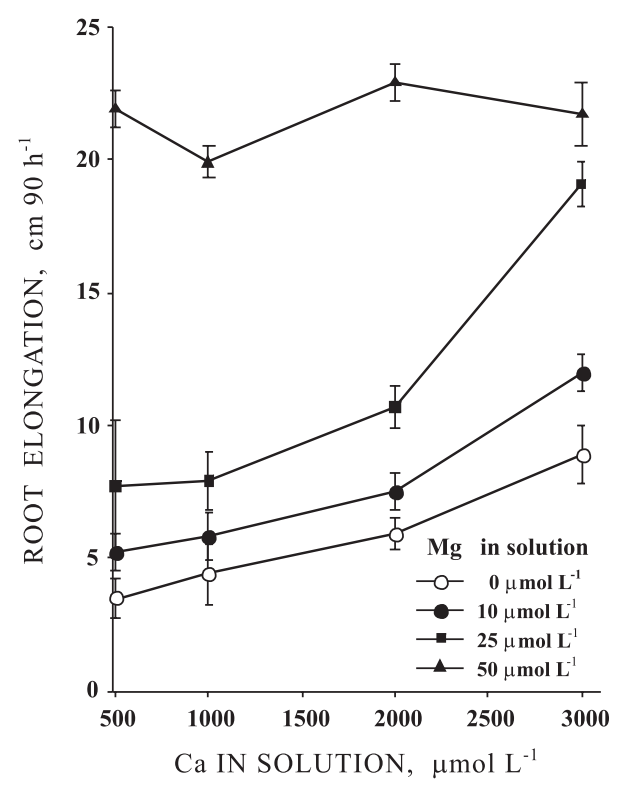

Figure 5. Relative root elongation of soybean cultivar Confiança as a function of increasing $\mathrm{Ca}$ and $\mathrm{Mg}$ in solution (pH 4.5), in the presence of $10 \mu \mathrm{mol} \mathrm{L} \mathrm{L}^{-1}$ Al. Error bars represent standard error $(n=3)$. 
Table 1. Selected chemical characteristics of the soil after establishing the treatments

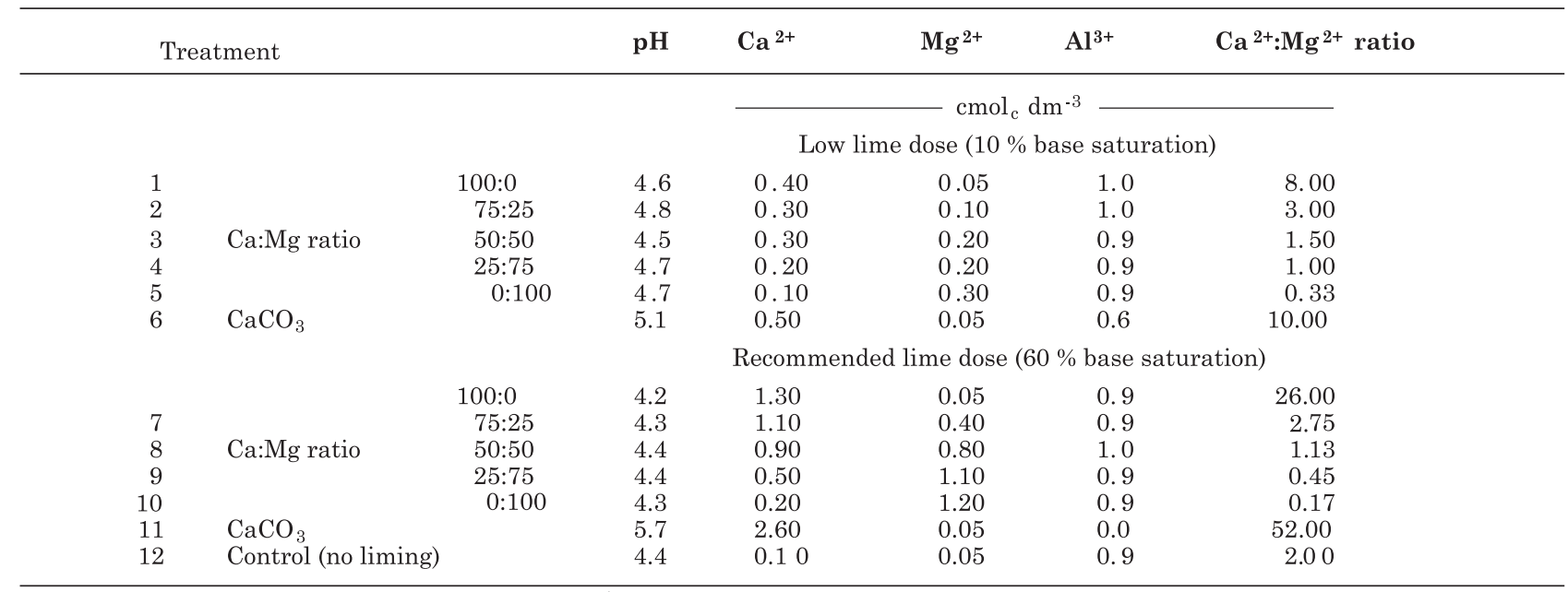

$\mathrm{pH}$ in $\mathrm{H}_{2} \mathrm{O}$ (2.5:1). $\mathrm{Al}, \mathrm{Ca}$ and $\mathrm{Mg}$ in the $1 \mathrm{~mol} \mathrm{~L}^{-1} \mathrm{KCl}$ extract.

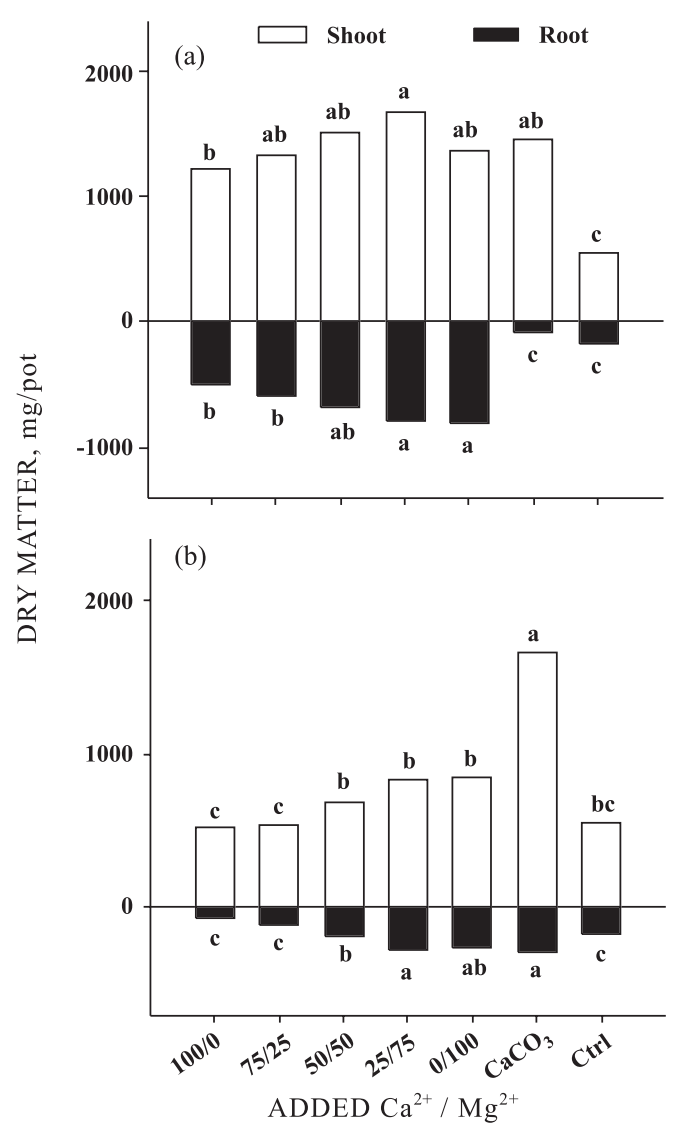

Figure 6. Dry matter production by soybean $\mathrm{cv}$. UFVS-2001 grown in an acid soil with variable $\mathrm{Ca}: \mathrm{Mg}$ ratios. (a) $10 \%$ base saturation; (b) $60 \%$ base saturation. Lime treatment received $\mathrm{CaCO}_{3}$ and all other nutrients, except Mg. Control (Ctrl) treatment received no liming, but the supply of all other nutrients, except $\mathrm{Ca}$ and $\mathrm{Mg}$, was ensured. Treatment means followed by the same letter are not significantly different by Tukey's test $(\alpha=0.05)$. enough to restrict root growth. In fact, $\mathrm{Al}^{3+}$ concentration above $0,3 \mathrm{cmol}_{\mathrm{c}} \mathrm{dm}^{-3}$ results in lower grain yield for several crops, including soybean (Nicolodi et al., 2008). Contrastingly, root elongation was increased by several orders of magnitude when $\mathrm{Mg}$ was added (Figure 6A), even though $0.9 \mathrm{cmol}_{\mathrm{c}} \mathrm{dm}^{-3} \mathrm{Al}^{3+}$ was still present (Table 1 ). The better root development at $10 \%$ than that at $60 \%$ base saturation in treatments with chloride salts may be due to chloride toxicity since the soil was a sandy loam and soybean is known to be chloride-sensitive (Pantalone et al., 1997).

The results also show that soybean plants grow well in a wide range of $\mathrm{Ca}: \mathrm{Mg}$ ratios, as long as $\mathrm{Al}^{3+}$ is absent. This is supported by the fact that plant growth was maximized in limed soil (60\% base saturation) at a Ca:Mg ratio of 52 (Figure 6), whereas at a lower $\mathrm{Ca}: \mathrm{Mg}$ ratio of 8 or 26 in soils of treatments 1 and 7 in which $\mathrm{Al}^{3+}$ was high, both shoot and root growth was reduced. It should be noted that even in the treatment with highest $\mathrm{Ca}: \mathrm{Mg}$ ratio shoot growth was lower than in limed soil (Figure 6), indicating that alleviation of $\mathrm{Al}$ toxicity was not complete, and greater amounts of the cation may be required for full protection. Although the application of greater $\mathrm{Ca}$ and $\mathrm{Mg}$ amounts ( $60 \%$ base saturation) led to higher levels of tissue $\mathrm{Ca}$ and $\mathrm{Mg}$ (compare Figure 7b,c with Figure 7e,f), the responses in shoot and root growth were not as positive as one would expect (compare Figure 6A to Figure 6B). Perhaps, growth was more limited as a result of a higher $\mathrm{Al}^{3+}$ concentration in the soil solution due to $\mathrm{Ca}$ and $\mathrm{Mg}$ displacement of exchangeable $\mathrm{Al}^{3+}$, which in turn led to a higher $\mathrm{Al}$ uptake (Figure 7). Additionally, the possibility of $\mathrm{Cl}^{-}$ toxicity can not be completely ruled out.

The chemical characteristics of the soil used here parallel those of acid subsoils, namely low exchangeable $\mathrm{Ca}^{2+}$ and $\mathrm{Mg}^{2+}$ and high $\mathrm{Al}^{3+}$. Hence, in acid subsoils as those in the Cerrado region of 

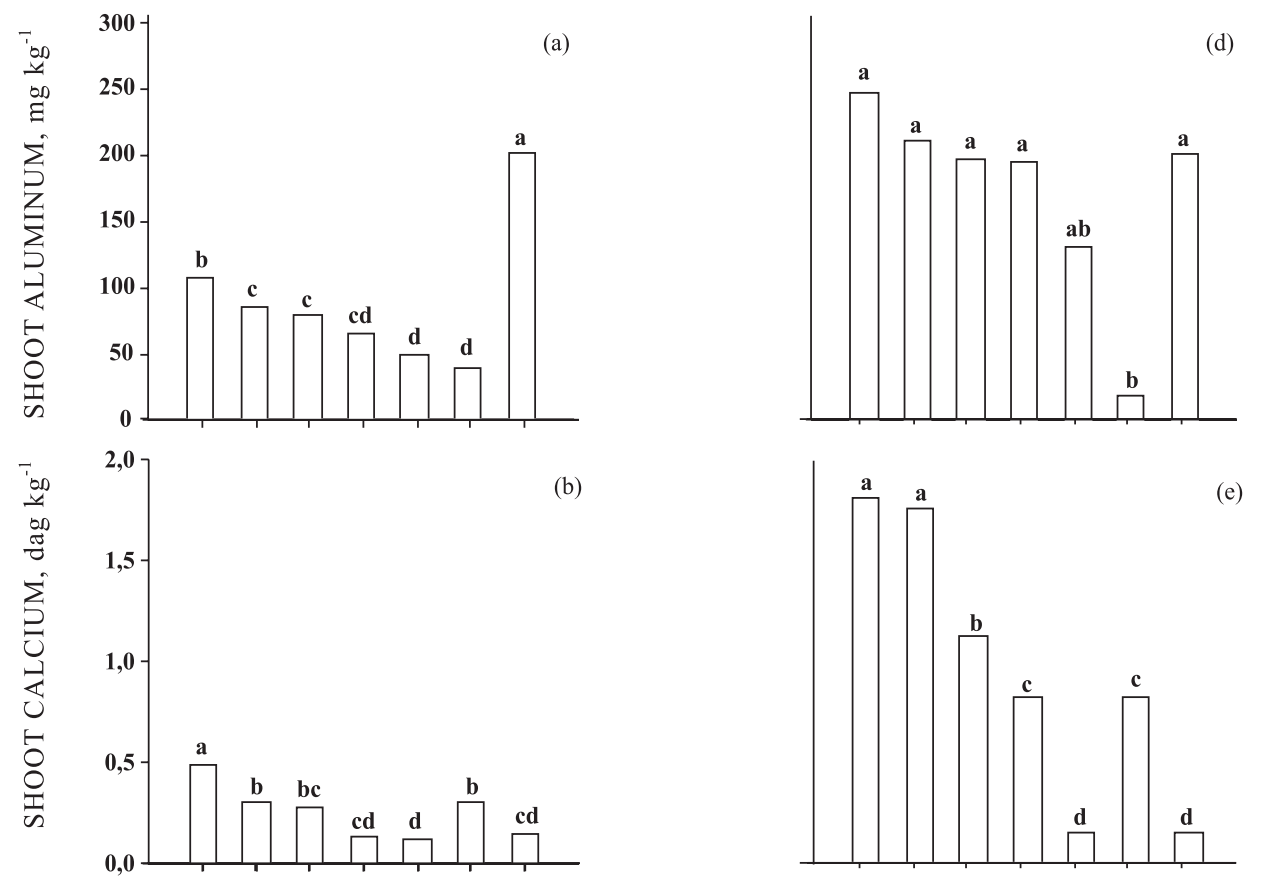

(d)
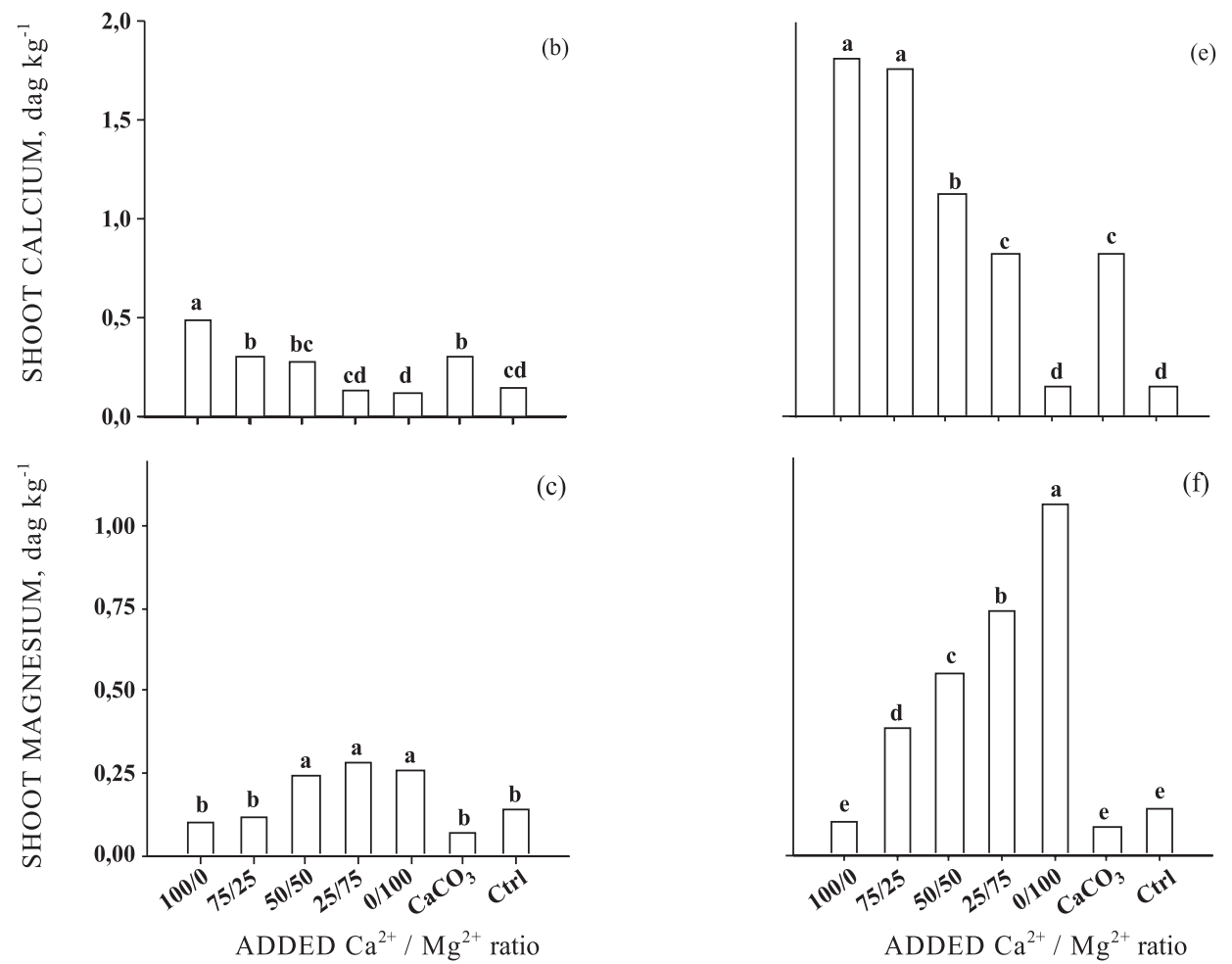

Figure 7. Shoot concentration of $\mathrm{Al}, \mathrm{Ca}$ and $\mathrm{Mg}$ of soybean cv. UFVS-2001 grown in an acid soil with variable Ca:Mg ratios. A-C 10 \% base saturation; D-F 60 \% base saturation. Lime treatment received $\mathrm{CaCO}_{3}$ and all other nutrients, except Mg. Control (Ctrl) treatment received no liming, but the supply of all other nutrients, except $\mathrm{Ca}$ and $\mathrm{Mg}$, was ensured. Treatment means followed by the same letter are not significantly different by Tukey's test $(\alpha=0.05)$.

Brazil, soybean rooting depth and drought resistance could be maximized by supplying not only a mobile source of $\mathrm{Ca}^{2+}$ (Ritchey et al., 1980; Lopes, 1996), but probably also $\mathrm{Mg}^{2+}$. Earlier studies have suggested that a similar soybean growth in acid soil could be obtained with lower lime rates if the amendment contained $\mathrm{Mg}^{2+}$ in addition to $\mathrm{Ca}^{2+}$ (Muchovej et al., 1986). Furthermore, it has been pointed out that responses to liming in high- $\mathrm{Al}^{3+}$, acid soils seem to be substantial under conditions with low $\mathrm{Mg}^{2+}$, even if $\mathrm{Ca}^{2+}$ is not limiting (Caires et al., 2003). Therefore, the importance of a $\mathrm{Mg}^{2+}$ source in areas where soybean is frequently used in crop rotations must not be overlooked. The observations that $\mathrm{Ca}^{2+}$ and $\mathrm{Mg}^{2+}$ from low solubility sources such as carbonate move downward in the soil profile under no-till conditions over time (Caires et al., 2000) further emphasizes the need to use dolomitic limestone, at least until $\mathrm{Mg}^{2+}$ levels in the (sub)soils are adequately raised.

\section{ACKNOWLEDGMENTS}

The authors are thankful to two anonymous reviewers and the assistant editor for their constructive questions and suggestions. Dr. I. R. Silva is grateful for the financial support from CNPqConselho Nacional de Desenvolvimento Científico e Tecnológico through grants 300543/00-0 and PROFIX grant No. 541090/01-1. Finaly, Dr. I.R. Silva would like to thank Prof. J.C. Ker for helping to select, classify and collect soil samples in the field. 


\section{LITERATURE CITED}

ALVA, A.K.; ASHER, C.J. \& EDWARDS, D.G. The role of calcium in alleviating aluminum toxicity. Aust. J. Agric. Res., 37:375-382, 1986.

CAIRES, E.F.; BLUM, J.; BARTH, G.; GARBUIO, F.J. \& KUSMAN, M.T. Alterações químicas do solo e resposta da soja ao calcário e gesso aplicados na implantação do sistema plantio direto. R. Bras. Ci. Solo, 27:275-286, 2003.

CAIRES, E.F.; FONSECA, A.F.; FELDHAUS, I.C. \& BLUM, J. Crescimento radicular e nutrição da soja cultivada no sistema plantio direto em resposta ao calcário e gesso na superfície. R. Bras. Ci. Solo, 25:1029-1040, 2001.

CAIRES, E.F.; BANZATO, D.A. \& FONSECA, A.F. Calagem na superfície em sistema plantio direto. R. Bras. Ci. Solo, 24:161-169, 2000

CAIRES, E.F.; CHUEIRI, W.A.; MADRUGA, E.F. \& FIGUEIREDO, A. Alterações de características químicas do solo e resposta da soja ao calcário e gesso aplicados na superfície em sistema de cultivo sem preparo do solo. $\mathrm{R}$. Bras. Ci. Solo, 22:27-34, 1998.

ESWARAN, H.; REICH, P. \& BEINROTH, F. Global distribution of soils with acidity. In: MONIZ, A.C.; FURLANI, A.M.C.; SHAFFERT, R.E; FAGERIA, N.K.; ROSOLEM, C.A. \& CANTARELLA, H., Eds. Plant-soil interaction at low pH: Sustainable agriculture and forestry production. Viçosa, MG, Brazilian Soil Science Society, 1997. p.159-164.

FAGERIA, N.K. Efeito da calagem na produção de arroz, feijão, milho e soja em solo de cerrado. Pesq. Agropec. Bras., 11:1419-1424, 2001.

FERRUFINO, A.; SMYTH, T.J.; ISRAEL, D.W. \& CARTER, T.E. Root elongation of soybean genotypes in response to acidity constraints in a subsurface solution compartment. Crop Sci., 40:413-421, 2000.

GRAUER, U.E. \& HORST, W.J. Modeling cation amelioration of aluminium phytotoxicity. Soil Sci. Soc. Am. J., 56:166172,1992

KINRAIDE, T.B. \& PARKER, D.R. Cation amelioration of aluminum toxicity in wheat. Plant Physiol., 83:546-551, 1987.

KINRAIDE, T.B. Identity of the rhizotoxic aluminum species. Plant Soil, 34:167-178, 1991.

KINRAIDE, T.B.; RYAN, P.R. \& KOCHIAN, L.V. Interactive effects of $\mathrm{Al}^{3+}, \mathrm{H}^{+}$, and other cations on root elongation considered in terms of cell-surface electrical potential. Plant Physiol., 99:1461-1468, 1992.

KINRAIDE, T.B. Use of a Gouy-Chapman-Stern model for membrane-surface electrical potential to interpret some features of mineral rhizotoxicity. Plant Physiol., 106:15861592, 1994a.

KINRAIDE, T.B.; RYAN, P.R. \& KOCHIAN, L.V. $\mathrm{Al}^{3+}{ }_{-} \mathrm{Ca}^{2+}$ interactions in aluminum rhizotoxicity-Evaluating the $\mathrm{Ca}^{2+}$-displacement hypothesis. Planta, 192:104-109, 1994b.

KINRAIDE, T.B. Three mechanisms for the calcium alleviation of mineral toxicities. Plant Physiol., 118:513-520, 1998.
KINRAIDE, T.B.; PEDLER, J.F. \& PARKER, D.R. Relative effectiveness of calcium and magnesium in the alleviation of rhizotoxicity in wheat induced by copper, zinc, aluminum, sodium, and low pH. Plant Soil, 259:201-208, 2004 .

LOPES, A.S. Soils under cerrado: A success story in soil management. Better Crops Int., 10:9-15, 1996.

LOPES, A.S. Solos sob "Cerrado": Características, propriedades e manejo. Piracicaba, Instituto do Potassa \& Fosfato, Instituto Internacional da Potassa, 1983. 162p.

MA, J.F.; DELHAIZE, E. \& RYAN, P.R. Aluminum tolerance in plants and the complexing role of organic acids. Trends Plant Sci., 6:273-278, 2001.

MACDIARMID, C.W. \& GARDNER, R.C. Al toxicity in yeasta role for Mg? Plant Physiol., 112:1101-1109, 1996.

MARSCHNER, H. Mineral nutrition of higher plants. San Diego, Academic Press, 1995. 889p.

MARTINS, O.C.; NOVAIS, R.F.; ALVAREZ V., V.H.; BARROS, N.F. \& RIBEIRO, A.C. Respostas à aplicação de diferentes misturas de calcário e gesso em solos, II. Crescimento de Raízes, absorção de nutrientes e produtividade de soja. R. Ceres, 45:451-466, 1998.

MENOSSO, O.G.; COSTA, J.A.; ANGHINONI, I. \& BOHNEN, H. Crescimento radicular e produção de ácidos orgânicos em cultivares de soja com diferentes tolerâncias ao alumínio. Pesq. Agropec. Bras., 11:1339-1345, 2001.

MENOSSO, O.G.; COSTA, J.A.; ANGHINONI, I. \& BOHNEN, H. Tolerância de genótipos de soja ao alumínio em solução. Pesq. Agropec. Bras., 11:2157-2166, 2000.

MOYER-HENRY, K.A.; SILVA, I.R.; JOHANNES, E.; ALLEN, N.S.; GOLDFARB, B.; JENNETTE, M.W. \& RUFTY, T.W. An evaluation of aluminum tolerance in loblolly pine.. In: ANNUAL MEETING OF THE AMERICAN SOCIETY OF PLANT BIOLOGY, 2003, Honolulu. Plant Biology 2003. Honolulu, 2003.

MUCHOVEJ, R.M.C.; BORGES, A.C.; NOVAIS, R.F. \& THIÉBAUT, J.T.L. Effect of liming level and Ca:Mg ratios on yield, nitrogen content and nodulation of soyabeans grown in acid cerrado soil. J. Soil Sci., 37:235-240, 1986.

NICOLODI, M.; ANGHINONI, I. \& GIANELLO, C. Indicadores da acidez do solo para recomendação de calagem no sistema plantio direto. R. Bras. Ci. Solo, 32:237-247, 2008.

NOVAIS, R.F.; NEVES, J.C.L. \& BARROS, N.F. Ensaio em ambiente controlado. In: EMPRESA BRASILEIRA DE PESQUISA AGROPECUÁRIA - EMBRAPA. Métodos de pesquisa em fertilidade do solo. Brasília, 1991. p.189-251.

OLIVEIRA, E.L. \& PAVAN, M.A. Control of soil acidity in notillage system for soybean production. Soil Till. Res., 38:4757, 1996.

O'NEILL, M.A.; WARRENFELTZ, D.; KATES, K.; PELLERIN, P.; DOCO, T.; DARVILL, A.G. \& ALBERSHEIM, P. Rhamnogalacturonan-II, a pectic polysaccharide in the walls of growing plant cell, forms a dimer that is covalently cross-linked by a borate ester. In vitro conditions for the formation and hydrolysis of the dimer. J. Biol. Chem., 271:22923-22930, 1996 
PANTALONE, V.R.; KENWORTHY, W.J.; SLAUGHTER, L.H. \& JAMES, B.R. Chloride tolerance in soybean and perennial Glycine accessions. Euphytica, 97:235-239, 1997.

PEDLER, J.F.; KINRAIDE, T.B. \& PARKER, D.R. Zinc rhizotoxicity in wheat and radish is alleviated by micromolar levels of magnesium and potassium in solution culture. Plant Soil., 259:191-199, 2004.

RITCHEY, K.D; SOUSA, D.M.G.; LOBATO E. \& CORREA O. Calcium leaching to increase rooting depth in a Brazilian Savannah Oxisol. Agron. J., 72:40-44, 1980.

RYAN, P.R.; DELHAIZE, E. \& JONES, D.L. Function and mechanism of organic anion exudation from plant roots. Ann. Rev. Plant Physiol. Plant Molec. Biol., 52:527-560, 2001.

SANZONOWICZ, C.; SMYTH, T.J. \& ISRAEL, D.W. Hydrogen and $\mathrm{Al}$ inhibition of soybean root extension from limed soil into acid subsurface solutions. J. Plant Nutr., 21:387403, 1998.

SARTAIN, J.B. \& KAMPRATH, E.J. Aluminum tolerance in soybean cultivars based on root elongation in solution culture compared with growth in acid soil. Agron. J., 70:17-20, 1978

SARRUGE, J.R. \& HAAG, H.P. Análises químicas em plantas. Piracicaba, Escola Superior de Agricultura Luiz de Queiroz, 1974. 56p.

SILVA, I.R.; SMYTH, T.J.; ISRAEL, D.W.; CARTER,T.E.; RAPER T.E. \& RUFTY, T.W. Differential aluminum tolerance in soybean: An evaluation of the role of organic acids. Physiol. Plant., 112, 200-210, 2001a.
SILVA, I.R.; SMYTH, T.J.; CARTER, T.E. \& RUFTY, T.W. Altered aluminum sensitivity in soybean genotypes in the presence of magnesium. Plant Soil, 230:223-230, 2001b.

SILVA, I.R.; SMYTH, T.J.; ISRAEL, D.W.; CARTER, T.E.; RAPER, T.E. \& RUFTY, T.W. Magnesium ameliorates aluminum rhizotoxicity in soybean by increasing citric acid production and exudation by roots. Plant Cell. Physiol., 42:546-554, 2001c.

SILVA, I.R.; SMYTH, T.J.; MOXLEY, D.F.; ALLEN, N.S. \& RUFTY, T.W. Aluminum accumulation at nuclei of cells in the root tip: Fluorescent detection using lumogallion and confocal laser scanning microscopy. Plant Physiol., 123:543-552, 2000.

SILVA, V.; MOTTA, A.C.V.; MELO, V.F. \& LIMA, V.C. Variáveis de acidez em função da mineralogia da fração argila do solo. R. Bras. Ci. Solo, 32:551-559, 2008.

SPEHAR, C.R. Aluminum tolerance of soya bean genotypes in short term experiments. Euphytica, 76:73-80, 1994.

TAN, K.; KELTJENS, W.G. \& FINDENEGG, G.R. Aluminum toxicity with sorghum genotypes in nutrient solutions and its amelioration by magnesium. J. Plant Nutr. Soil Sci., 155:81-86, 1992.

YANG, M.Z.; SIVAGURU, M.; HORST, W.J. \& MATSUMOTO $\mathrm{H}$. Aluminum tolerance is achieved by exudation of citric acid from soybean roots. Physiol. Plant., 110:72-77, 2000. 